\title{
OPEN Abiotic stressors impact outer membrane vesicle composition in a beneficial rhizobacterium: Raman spectroscopy characterization
}

\begin{abstract}
Matthew Potter, Cynthia Hanson, Anne J. Anderson, Elizabeth Vargis ${ }^{\bowtie}$ \& David W. Britt ${ }^{\bowtie}$
Outer membrane vesicles (OMVs) produced by Gram-negative bacteria have roles in cell-to-cell signaling, biofilm formation, and stress responses. Here, the effects of abiotic stressors on OMV contents and composition from biofilm cells of the plant health-promoting bacterium Pseudomonas chlororaphis $\mathrm{O} 6$ (PcO6) are examined. Two stressors relevant to this root-colonizing bacterium were examined: $\mathrm{CuO}$ nanoparticles (NPs)-a potential fertilizer and fungicide- and $\mathrm{H}_{2} \mathrm{O}_{2}$-released from roots during plant stress responses. Atomic force microscopy revealed 40-300 nm diameter OMVs from control and stressed biofilm cells. Raman spectroscopy with linear discriminant analysis (LDA) was used to identify changes in chemical profiles of $\mathrm{PCO} 6$ cells and resultant OMVs according to the cellular stressor with $\mathbf{8 4 . 7 \%}$ and $83.3 \%$ accuracies, respectively. All OMVs had higher relative concentrations of proteins, lipids, and nucleic acids than $\mathrm{PcO} 6$ cells. The nucleic acid concentration in OMVs exhibited a cellular stressor-dependent increase: $\mathrm{CuO}$ NP-induced $\mathrm{OMVs}>\mathrm{H}_{2} \mathrm{O}_{2}$-induced OMVs $>$ control OMVs. Biochemical assays confirmed the presence of lipopolysaccharides, nucleic acids, and protein in OMVs; however, these assays did not discriminate OMV composition according to the cellular stressor. These results demonstrate the sensitivity of Raman spectroscopy using LDA to characterize and distinguish cellular stress effects on OMVs composition and contents.
\end{abstract}

Outer membrane vesicles (OMVs) are extracellular vesicles produced by Gram-negative bacteria, ranging from 20-300 nm in diameter ${ }^{1-3}$. OMV composition includes numerous outer membrane and periplasmic components such as proteins, lipopolysaccharide (LPS), enzymes, and in the case of pathogens, toxins ${ }^{4}$. OMVs may also contain $\mathrm{DNA}^{5,6}$ or RNA ${ }^{7}$. Consequently, OMV formation and release exhibit many unique functions including acting as a protein secretion system ${ }^{8}$, delivering virulence factors by pathogenic bacteria ${ }^{9-11}$, and signaling between bacteria ${ }^{12,13}$ and cross-kingdom with eukaryotic cells ${ }^{9,13,14}$. OMVs are released during all stages of cell growth in liquid and solid culture ${ }^{15}$. OMVs are released in biofilms and are a part of the extracellular matrix in naturally-occurring and laboratory-grown biofilms ${ }^{16}$. OMVs may mediate biofilm formation ${ }^{17}$. For several Helicobacter pylori strains, OMV production correlates with the ability to form and maintain the biofilm ${ }^{18}$. The quorum-sensing molecule 2-heptyl-3-hydroxy-4-quinolone, used for communication during biofilm formation by Pseudomonas aeruginosa, is present within P. aeruginosa-produced $\mathrm{OMVs}^{19}$ and is required for OMV formation by this bacterium ${ }^{20}$.

Although OMVs are continually released, OMV production increases in response to stress ${ }^{21,22}$, possibly as a mechanism to quickly release misfolded periplasmic proteins ${ }^{22,23}$. OMV production under stress also appears to have defensive roles. OMVs are decoys for bacteriophages and other membrane-binding antimicrobial agents thus distancing their potential to impact the live cell ${ }^{24}$. OMVs may contain specific enzymes and other compounds to increase bacterial survival ${ }^{1,25,26}$. For example, exposure to reactive oxygen species (ROS), such as $\mathrm{H}_{2} \mathrm{O}_{2}$, increases OMV release in several bacteria ${ }^{21,27,28}$. However, $H$. pylori release catalase-containing OMVs in response to ROS stress thus protecting cells from oxidative damage ${ }^{28}$. Another example is packaging $\beta$-lactamase into OMVs by Moraxella catarrhalis to inactivate $\beta$-lactam antibiotics ${ }^{29}$. 
Virulence and signaling through OMVs released by human pathogens ${ }^{11,30}$ and plant pathogens $s^{31,32}$ have been investigated for managing infections. In contrast, factors stimulating OMV release and OMV roles for plant health-promoting bacteria are generally unknown. The beneficial relationship between the plant and its associated microbiome requires cross-kingdom signaling that is mediated through many small metabolites, including hormones and quorum sensing molecules ${ }^{33,34}$. OMV release presents one potential method for the secretion and delivery of these signals.

The potential packaging of nucleic acids and LPS into OMVs may be important as signals to the plant which then activates plant defenses. LPS is a microbe-associated molecular pattern (MAMP) and DNA fragments are damage-associated molecular patterns (DAMPs) recognized by specific plant cell receptors to trigger innate immunity $^{35}$. OMVs contain large quantities of LPS ${ }^{36}$, likely due to the high surface area of these nano-vesicles. OMVs released by $P$. aeruginosa may contain plasmid $\mathrm{DNA}^{12}$, coding chromosomal $\mathrm{DNA}^{5}$, or noncoding extracellular DNA (eDNA) ${ }^{37}$.

Here, OMVs of a plant health-promoting bacterium, Pseudomonas chlororaphis O6 (PcO6), were studied. PcO6 is a Gram-negative, rod-shaped bacterium originally isolated from roots of commercial dryland wheat grown in Cache Valley, UT, USA ${ }^{38}$. PcO6 is representative of many beneficial soil bacteria, boosting plant health through multiple protective pathways. $\mathrm{PcO} 6$ is an aggressive root colonizer and forms robust biofilms on plant roots $^{39,40}$ and abiotic surfaces ${ }^{41}$. Cell growth within the biofilm is nurtured through catabolism of the metabolites in the root exudates ${ }^{41}$. In return, the bacterium protects the host by producing phenazines and other antibacterial and antifungal compounds as well as triggering systemic resistance ${ }^{42}$. PcO6 protects plants from drought, in part by producing a volatile, butanediol, that triggers partial stomatal closure ${ }^{43}$. Biofilm formation may also promote crop drought tolerance because the biofilm matrix maintains moisture around the plant roots ${ }^{44,45}$.

Potential OMVs are observed in atomic force microscopy images of $P_{c} \mathrm{O} 6 \mathrm{cells}^{46,47}$, but OMV composition and their role in $\mathrm{PcO} 6$ signaling, biofilm architecture, and stress responses are currently unknown. Two relevant stressors to the rhizosphere, the space around plant roots, and their effects on PcO6 and subsequent OMV production were examined in this study. The first stressor was $\mathrm{CuO}$ nanoparticles (NPs). Numerous engineered metal and metal oxide NPs are explored for agricultural applications including delivering macronutrient and micronutrient to crops $s^{48,49}$, controlling pests and pathogens ${ }^{49}$, and protecting crops against abiotic stresses ${ }^{50}$ such as drought ${ }^{40,49,51,52}$. In some cases, NPs enhance microbial synthesis of products that improve plant health ${ }^{53}$.

In PcO6-colonized wheat, $\mathrm{CuO}$ NPs upregulate genes associated with drought tolerance ${ }^{52}$ and increase lignification in wheat sclerenchyma, a strengthening tissue of the plant ${ }^{40}$. Thus NP-induced gene expression can contribute to crop stress tolerance ${ }^{52,54}$. NPs also change gene expression in various beneficial and antagonistic microorganisms ${ }^{54}$. Sublethal doses of $\mathrm{CuO}$ NPs increase PcO6 cell size without impeding biofilm formation ${ }^{41}$, decrease the production of the Fe-scavenging siderophore pyoverdine ${ }^{55}$, and increase the production of the plant growth regulator indole-3-acetic acid ${ }^{56}$. Hydrogen peroxide $\left(\mathrm{H}_{2} \mathrm{O}_{2}\right)$ was examined as a second bacterial stressor as ROS are generated as a stress response by plant root cells ${ }^{57}$, including roots exposed to sublethal $\mathrm{CuO}$ NP challenges ${ }^{58}$.

To characterize OMVs, as well as any compositional changes due to these abiotic stressors, Raman spectroscopy was chosen as the primary analytical technique. Compared to other spectroscopy methods, Raman spectroscopy is well suited for biological samples as it requires minimal sample preparation, is non-destructive, and yields a linear correlation of compound concentration to signal strength ${ }^{59}$. Raman spectroscopy is regularly used for cellular identification and characterization, even at a single-cell level ${ }^{60-62}$. Changes in biomolecular profiles according to the growth stage can be detected by Raman spectroscopy in mycobacterial cells ${ }^{63}$. Raman spectroscopy has been used to characterize extracellular vesicles from eukaryotic cells ${ }^{64-66}$, but no current literature reports Raman spectroscopy characterization of OMVs.

Raman spectroscopy was used to explore the chemical signatures of biofilm PcO6 cells under baseline conditions and after exposure to sublethal doses of $\mathrm{CuO} \mathrm{NP}$ or $\mathrm{H}_{2} \mathrm{O}_{2}$. OMVs were isolated and characterized from both control and stressed cells. Spectra were compared using linear discriminant analysis (LDA). This machine learning technique creates an algorithm to sort input data sets according to treatments, then uses the algorithm to predict the treatments of the input data sets. The actual treatment and predicted treatment are then compared to determine consistencies and variations between spectra. Biochemical assays detecting protein, LPS, and DNA concentrations were performed to measure their presence in OMVs and to further examine changes in OMV composition.

\section{Results}

Physical characterization of outer membrane vesicles. OMV production by PcO6 biofilm cells was confirmed in situ with imaging by atomic force microscopy (AFM) and scanning electron microscopy (SEM). AFM images of $\mathrm{PcO} 6$ biofilm cells, transferred from minimal medium agar plates, without stressors show OMVs as aggregates between $\mathrm{PcO} 6$ cells (Fig. 1a) and as linear assemblies apart from the cells (Fig. 1b). Purified control and stress-induced OMVs appear as clustered and linear aggregates in AFM images (Fig. 2). SEM analysis also reveals a propensity of purified OMVs to aggregate (Fig. 3). SEM images of PcO6 biofilms formed on hollow fiber membranes draped in minimal medium, a substrate that allows imaging of intact biofilms encased in extracellular polymeric substances, also showed OMVs as part of the biofilm matrix as well as budding from and/or adhered to cells (Fig. 3b).

Size analysis of the OMVs in the AFM images $(n=100$ from four images per treatment) showed average diameters of individual OMVs in the range of 40-190 nm, 45-295 nm, and 45-140 nm for control, CuO NPinduced, and $\mathrm{H}_{2} \mathrm{O}_{2}$-induced OMVs (Supplemental Fig. S2). Two-way ANOVA of the data, accounting for the treatment and the image used, showed statistically significant differences ( $p$-value $<0.05$ ) between several images within each treatment (data not shown) leaving uncertainty for the results comparing OMVs from one treatment. 

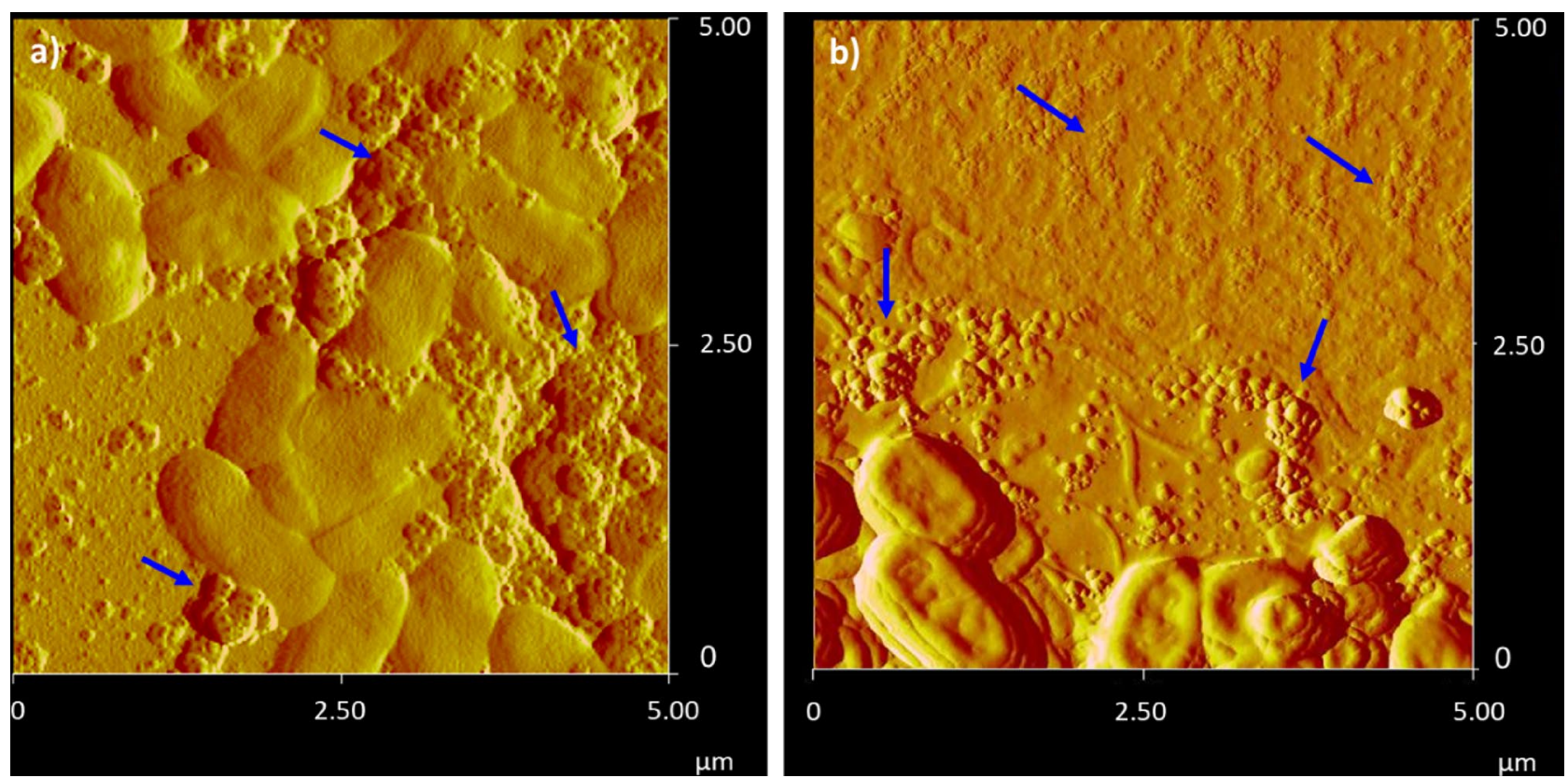

Figure 1. AFM amplitude images of cells from the edges of a PcO6 cell smear from a biofilm grown on a $2 \%$ agar minimal medium plate onto a clean glass slide. OMVs are visible in both images as (a) aggregates between PcO6 cells and (b) as linear assemblies. Arrows point to examples of these OMV aggregates.
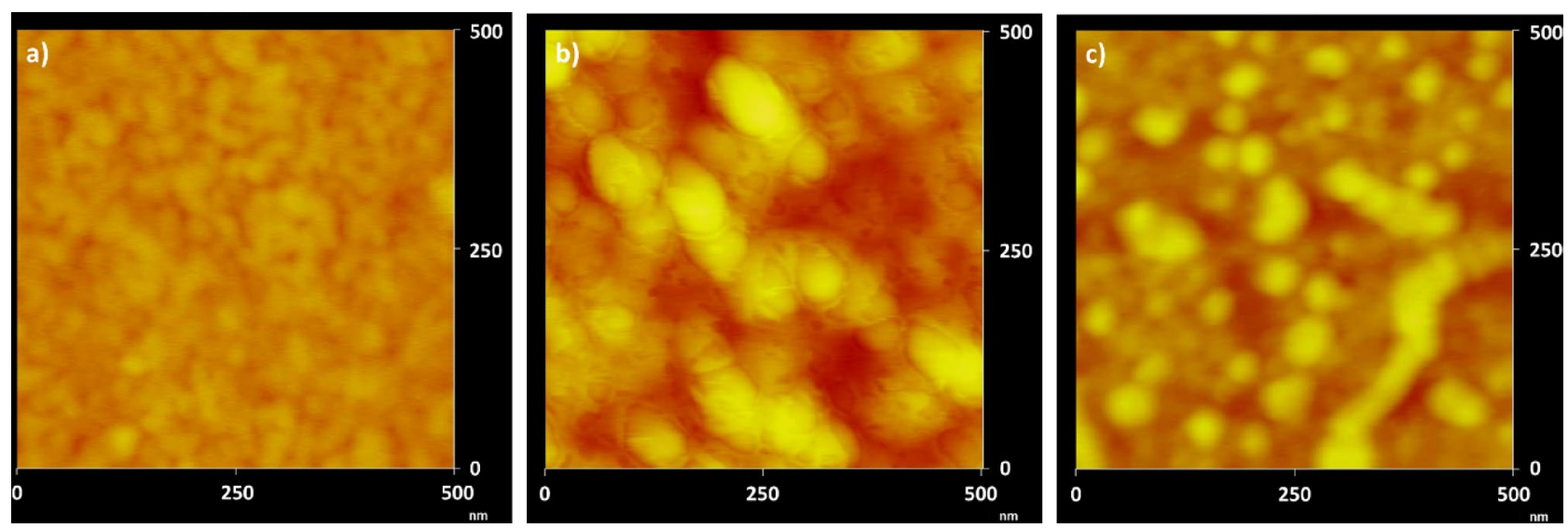

Figure 2. AFM height images of purified OMVs. Z-scales are from red to yellow from 0 to $25 \mathrm{~nm}$, respectively. (a) OMVs harvested from PcO6 without any stressors. (b) OMVs harvested from $P c \mathrm{O} 6$ under $\mathrm{H}_{2} \mathrm{O}_{2}$ stress $(3 \%$ $\mathrm{v} / \mathrm{v})$. (c) OMVs harvested from $\mathrm{PcO} 6$ under $\mathrm{CuO}$ NP stress $(30 \mathrm{mg} \mathrm{Cu} / \mathrm{L})$. Additional AFM images shown in Supplemental Fig. S1.

Furthermore, OMV heights in AFM images were a fraction of the OMV width, only 5-15 nm (data not shown), implying that the OMVs flattened during sample desiccation and these diameters may not represent true in vivo OMV size. These size ranges and this potential vesicle flattening has been observed by other researchers imaging vesicles with $\mathrm{AFM}^{67}$.

Both AFM and SEM images revealed agglomerate structures comprised of individual OMVs with clearly defined boundaries between vesicles. This propensity for OMV aggregation was confirmed with dynamic light scattering (DLS) which revealed hydrodynamic diameters ranging from 40-300 nm (Supplemental Fig. S3). The imaging and DLS results are consistent with literature reports of OMV diameters between 10 and $300 \mathrm{~nm}^{11,68}$.

Chemical characterization of PcO6 cells with Raman spectroscopy. Raman spectroscopy was coupled with LDA to detect differences in the chemical profiles of control and stressed PcO6 cells. Raman spectra of whole biofilm PcO6 cells ( $\mathrm{n}=24$ from 6 replicates), normalized to the highest peak of $2935 \mathrm{~cm}^{-1}(\mathrm{C}-\mathrm{H}$ bonds and lipid $\mathrm{C}-\mathrm{H}_{3}$ bonds), from each treatment are shown in Fig. 4 . The $2935 \mathrm{~cm}^{-1}$ peak was selected for normalization as it correlates to $\mathrm{C}-\mathrm{H}$ bonds from all biological molecules and lipid $\mathrm{C}-\mathrm{H}_{3}$ bonds. Both of these bonds are plentiful in phospholipids that are present in OMV membranes, making this peak ideal for normalization. 
a)

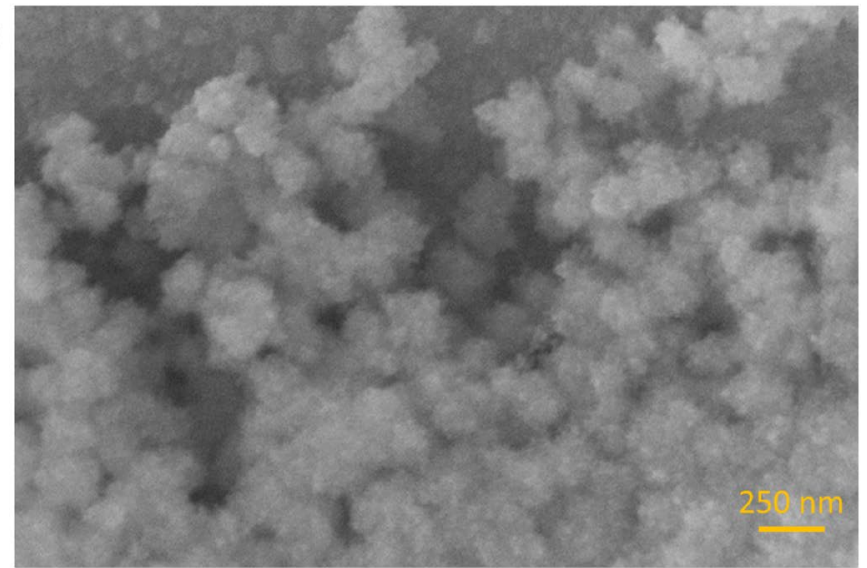

b)

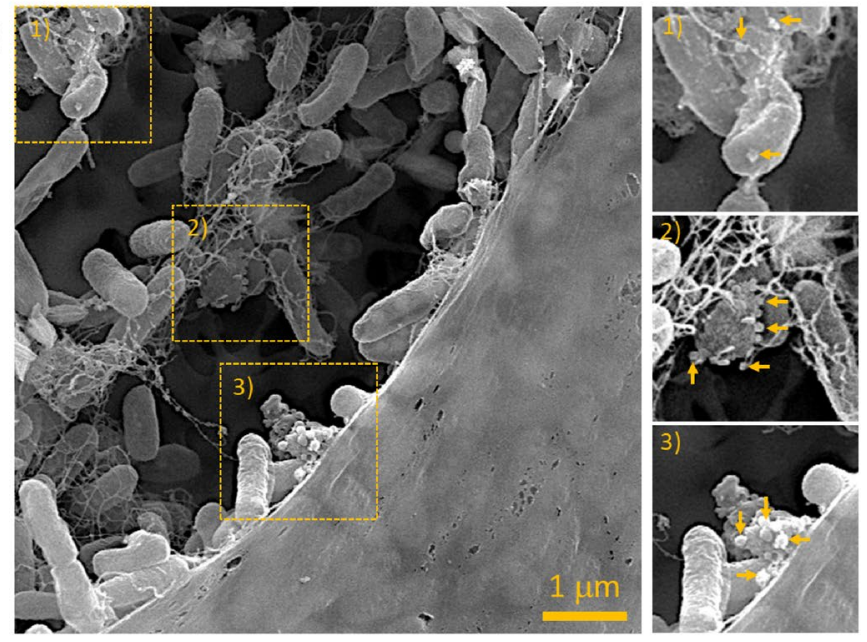

Figure 3. SEM images of $P c O 6$ cells and purified OMVs. (a) SEM image showing OMV aggregation of samples purified from $\mathrm{PcO} 6$ biofilms grown on minimal medium plates without abiotic stressors after glutaraldehyde fixation and ethanol dehydration. (b) SEM image showing the cross-section of a PcO6 biofilm grown on a hollow fiber membrane draped in minimal medium without any added stressors. Three areas of this image are highlighted to show potential OMVs which are marked with arrows.

Peak assignments were consistent with proteins containing amino acids such as phenylalanine and tyrosine as well as unsaturated lipids and polysaccharides. The signatures of bases adenine, uracil, and guanine indicate the presence of nucleic acids. A full list of peak assignments is shown in Supplemental Table S1. There were no peaks unique for any treatment nor any peaks that disappeared in any one treatment. However, peak intensities differed between treatments with the spectra of control PcO6 giving the highest relative intensities, followed by $\mathrm{H}_{2} \mathrm{O}_{2}$-treated $\mathrm{PcO}$, then $\mathrm{CuO}$ NP-treated PcO6. The following peaks showed the greatest decreases in peak intensity for stressed cells relative to the control: (a) $880 \mathrm{~cm}^{-1}$ : tryptophan and lipid $\mathrm{N}^{+}\left(\mathrm{CH}_{3}\right)_{3}$ bonds; (b) 1220-1280 $\mathrm{cm}^{-1}$ : amide III; (c) 1330-1340 $\mathrm{cm}^{-1}$ : adenine, guanine, tyrosine, and tryptophan; (d) $1365 \mathrm{~cm}^{-1}$ : lipid $\mathrm{C}-\mathrm{H}$ bonds; (e) $1450 \mathrm{~cm}^{-1}$ : protein and lipid C-H bonds; and f) $1660 \mathrm{~cm}^{-1}$ : unsaturated lipids.

Examining the majority of the Raman spectra $\left(750-1700\right.$ and $\left.2670-3100 \mathrm{~cm}^{-1}\right)$ with LDA, it is apparent that PcO6 cells exhibit distinct chemical profiles according to the applied stressor (LDA plot shown in Figure 5 and LDA confusion matrix are shown in Table 1). Though several spectra are misclassified from each treatment, the algorithm had an $84.7 \%$ accuracy. LDA was also performed on narrower regions of the Raman spectra (Supplemental Fig. S4) to correlate how restricted input data sets influenced LDA grouping and accuracy. LDA results of spectra subsets trended towards increased distance between data groupings. Accuracy of the LDA assignment varied between spectral regions.

The LDA plot of the $2670-3100 \mathrm{~cm}^{-1}$ showed loose grouping of the treatments and the lowest accuracy of the examined regions was $82 \%$ (Supplemental Fig. S4b). This region of the spectra corresponds with several C-H and $\mathrm{C}-\mathrm{H}_{2}$ signatures which would be unlikely to change across experimental groups. This region also contains the $2935 \mathrm{~cm}^{-1}$ peak (C-H bonds) which was the highest peak in all spectra and used to normalize the spectra. By contrast, LDA of lower wavenumbers tended to show tighter and more distinct groupings and higher accuracy. This is especially notable in the $1400-1500 \mathrm{~cm}^{-1}$ region (Supplemental Fig. S4f) and the $1500-1700 \mathrm{~cm}^{-1}$ region (Supplemental Fig. S4g) which both gave $94.4 \%$ accuracies. All treatments are distinctly grouped in these LDA plots, especially the $\mathrm{H}_{2} \mathrm{O}_{2}$ treatment in the $1400-1500 \mathrm{~cm}^{-1}$ region and the CuO NP treatment in the $1500-1700 \mathrm{~cm}^{-1}$ region. The $1400-1500 \mathrm{~cm}^{-1}$ region contains several protein signatures. The $1500-1700 \mathrm{~cm}^{-1}$ 
a)

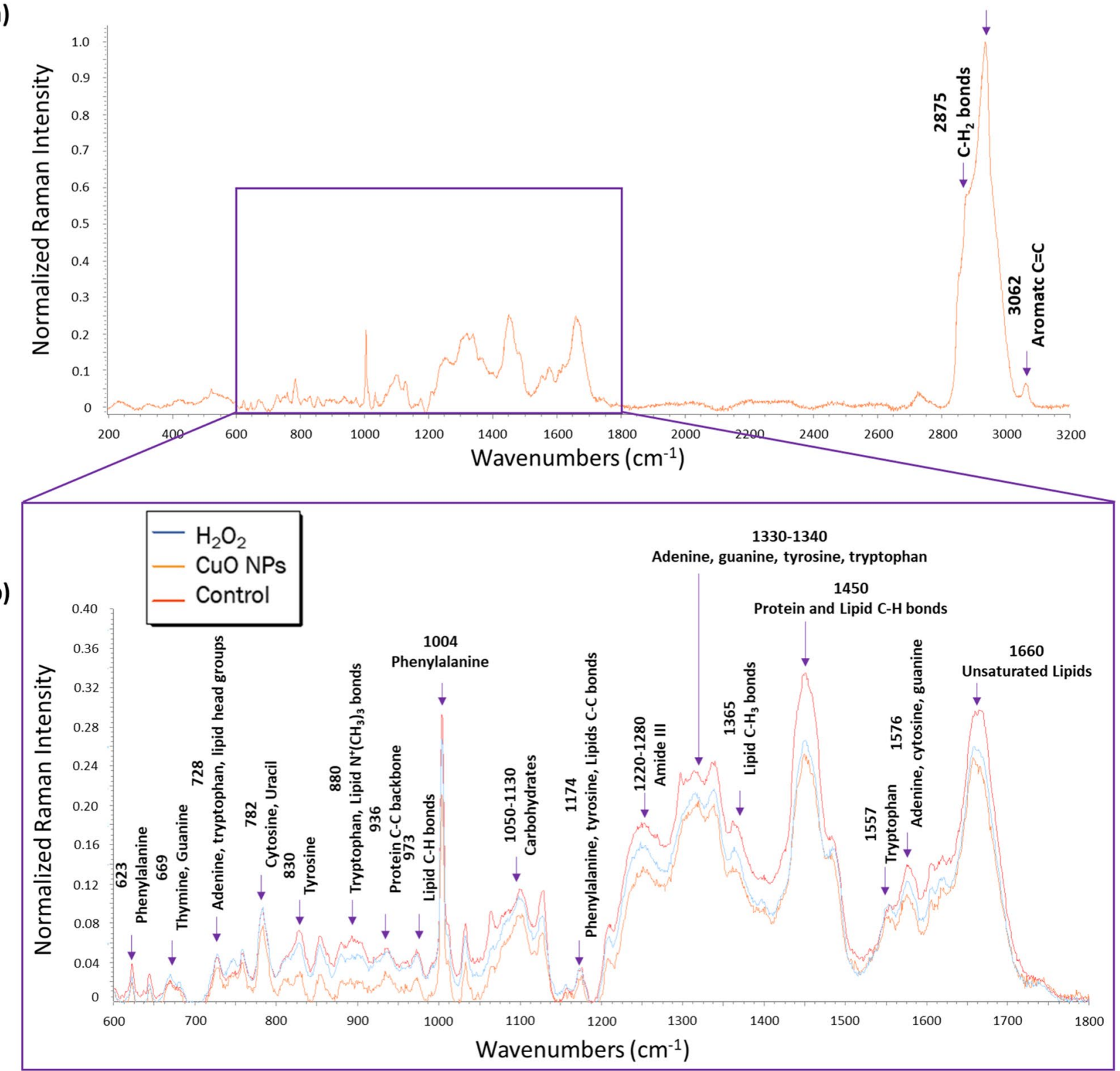

Figure 4. Averaged Raman spectra of intact PcO6 cells ( 6 replicates with 4 spectra each for a total of $\mathrm{n}=24$ ). (a) Averaged Raman spectra of PcO6 cells without any applied stressor from 600 to $3200 \mathrm{~cm}^{-1}$. No visible differences are seen in the relative peak intensities above $1800 \mathrm{~cm}^{-1}$ of $P c \mathrm{O} 6$ cells of each treatment so spectra of $\mathrm{CuONP}$ and $\mathrm{H}_{2} \mathrm{O}_{2}$ treated cells are not shown. (b) Averaged Raman spectra of PcO6 cells treated with $\mathrm{H}_{2} \mathrm{O}_{2}$ stress, $\mathrm{CuO} N \mathrm{NP}$ stress, and a negative control with no added stressor from 600 to $1800 \mathrm{~cm}^{-1}$. In this region, differences are seen in relative peak intensity indicating differences in relative concentrations of various compounds. In both graphs, notable peak assignments are shown with an arrow and labeled with both the peak number and peak assignment. See Supplemental Table S1 for a list of all peak assignments and respective sources.

region contains various amino acid, nucleic acid, amide, and lipid signatures (see Supplemental Table S1 for a list of all peak assignments).

Comparing Raman spectra of PcO6 cells and isolated OMVs. Raman spectroscopy was used to compare the chemical profiles of $\mathrm{PcO} 6$ cells and isolated OMVs. Unique peaks were found in comparisons between Raman spectra of control biofilm PcO6 cells and purified OMVs from control cells (Fig. 6): 27 peaks are unique to PcO6 cells, 14 peaks are unique to OMVs, and 10 peaks are shared (a full list of peak assignments for PcO6 cells and OMVs is shown in Supplemental Table S1). Figure 6 shows these shared peak assignments, and 


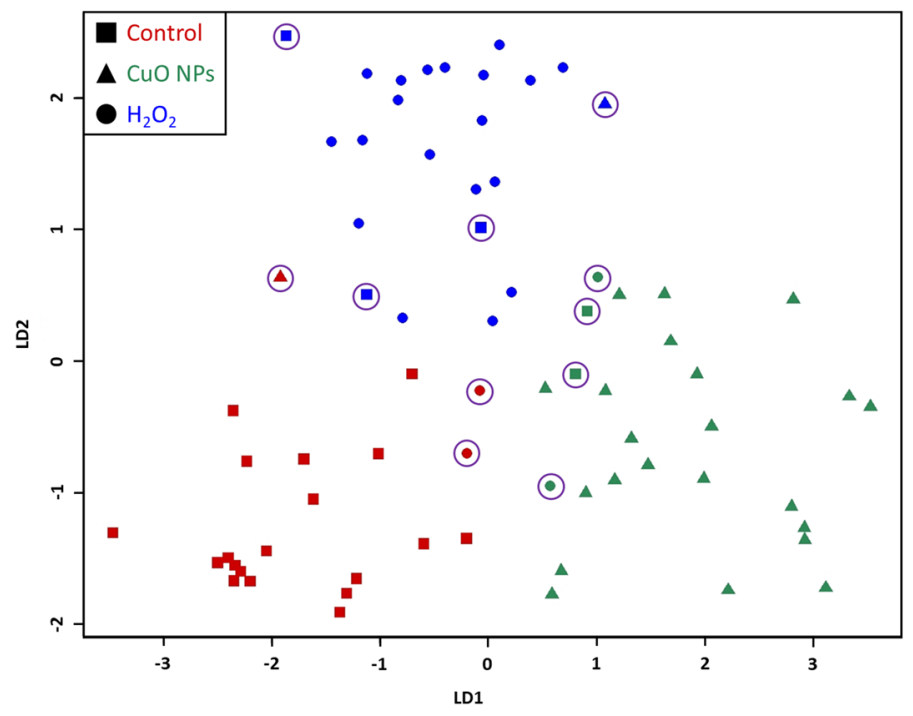

Figure 5. LDA plot of Raman spectra from PcO6 cells. Data were truncated to $750-1700 \mathrm{~cm}^{-1}$ and $2670-$ $3100 \mathrm{~cm}^{-1}$, where most peaks are located. The shape of the points of the plot indicate the true treatment of each spectrum whereas the color of the point indicates the predicted treatment according to LDA. Misclassified spectra are circled in purple.

\begin{tabular}{|c|c|c|c|c|}
\hline \multicolumn{5}{|c|}{ Confusion matrix of Raman spectra of $P c 06$ cells } \\
\hline & & \multicolumn{3}{|c|}{ Predicted treatment } \\
\hline & & Control & CuO NPs & $\mathrm{H}_{2} \mathrm{O}_{2}$ \\
\hline \multirow{3}{*}{ True treatment } & Control & 19 & 2 & 3 \\
\hline & $\mathrm{CuONPs}$ & 1 & 22 & 1 \\
\hline & $\mathrm{H}_{2} \mathrm{O}_{2}$ & 2 & 2 & 20 \\
\hline
\end{tabular}

Table 1. Confusion matrix showing LDA results of Raman spectra from PcO6 cells. Data were truncated to $750-1700 \mathrm{~cm}^{-1}$ and $2670-3100 \mathrm{~cm}^{-1}$, where most peaks are located. LDA of the Raman spectra gave an $84.7 \%$ accuracy indicating that spectra of $\mathrm{PcO} 6$ cells are highly dependent on the stressor.

whether relative peak intensity is higher for control $\mathrm{PcO} 6$ cells or resultant purified OMVs. The same trends were seen in $\mathrm{H}_{2} \mathrm{O}_{2}$ and $\mathrm{CuO}$ NP-treated PcO6 cells and purified OMVs of stressed cells (data not shown).

The relative intensity differed between shared peaks. All but two of these shared peaks had higher relative intensity for the OMV spectra than spectra of intact $P c \mathrm{O} 6$ cells. Though there are few peaks shared by intact $P c \mathrm{O} 6$ cells and purified OMVs, several unique peaks for $P c \mathrm{O} 6$ and OMV Raman spectra correspond to the same chemical compounds: i.e. PcO6 peak $644 \mathrm{~cm}^{-1}$ and OMV peak $870 \mathrm{~cm}^{-1}$ both correspond with tyrosine. Raman peaks assigned to the amino acid tryptophan and the nucleic acid bases adenine, cytosine, and guanine are present in spectra PcO6 cells and purified OMVs. However, the peaks assigned to these chemistries differ between the spectra for intact biofilm cells and the isolated OMVs. Both PcO6 and OMV spectra show various lipid, carbohydrate, protein, and nucleic acid signatures although different signatures of these macromolecules appear in each: i.e. PcO6 peak $810 \mathrm{~cm}^{-1}$ indicates lipid O-P-O bonds while OMV peak $1092 \mathrm{~cm}^{-1}$ indicates lipid C-C bond (Supplemental Table S1).

Especially notable in Raman spectra of isolated OMVs was the increased intensity of nucleic acid peaks which implies that DNA and/or RNA are selectively packaged by PcO6 into and/or onto OMVs. This conclusion was confirmed by measuring OMV 260/280 UV-absorption ratios, which compares the concentration of nucleic acids to the concentration of protein at their respective absorption peaks of 260 and $280 \mathrm{~nm}$. OMV 260/280 ratios did not vary according to cell stressor (Supplemental Table S2) with an overall mean of 5.91 \pm 0.09 . Generally, a 260/280 ratio above 1.8 is obtained with a pure DNA sample and 2.0 is obtained with a pure RNA sample. The micro-BCA assay results confirmed varying amounts of protein in OMV suspensions (Supplemental Fig. S5b). These high 260/280 ratios for OMVs could be due to other compounds within OMVs that absorb light at similar wavelengths. $\mathrm{PcO} 6$ is known to secrete several secondary metabolites including phenazines and siderophores ${ }^{42}$ and these results suggest that some metabolites may be packaged into OMVs.

Chemical characterization of stress-induced outer membrane vesicles with Raman spectroscopy. The chemical profiles of control OMVs were compared with $\mathrm{H}_{2} \mathrm{O}_{2}$ - and $\mathrm{CuO} \mathrm{NP}$-induced OMVs with 


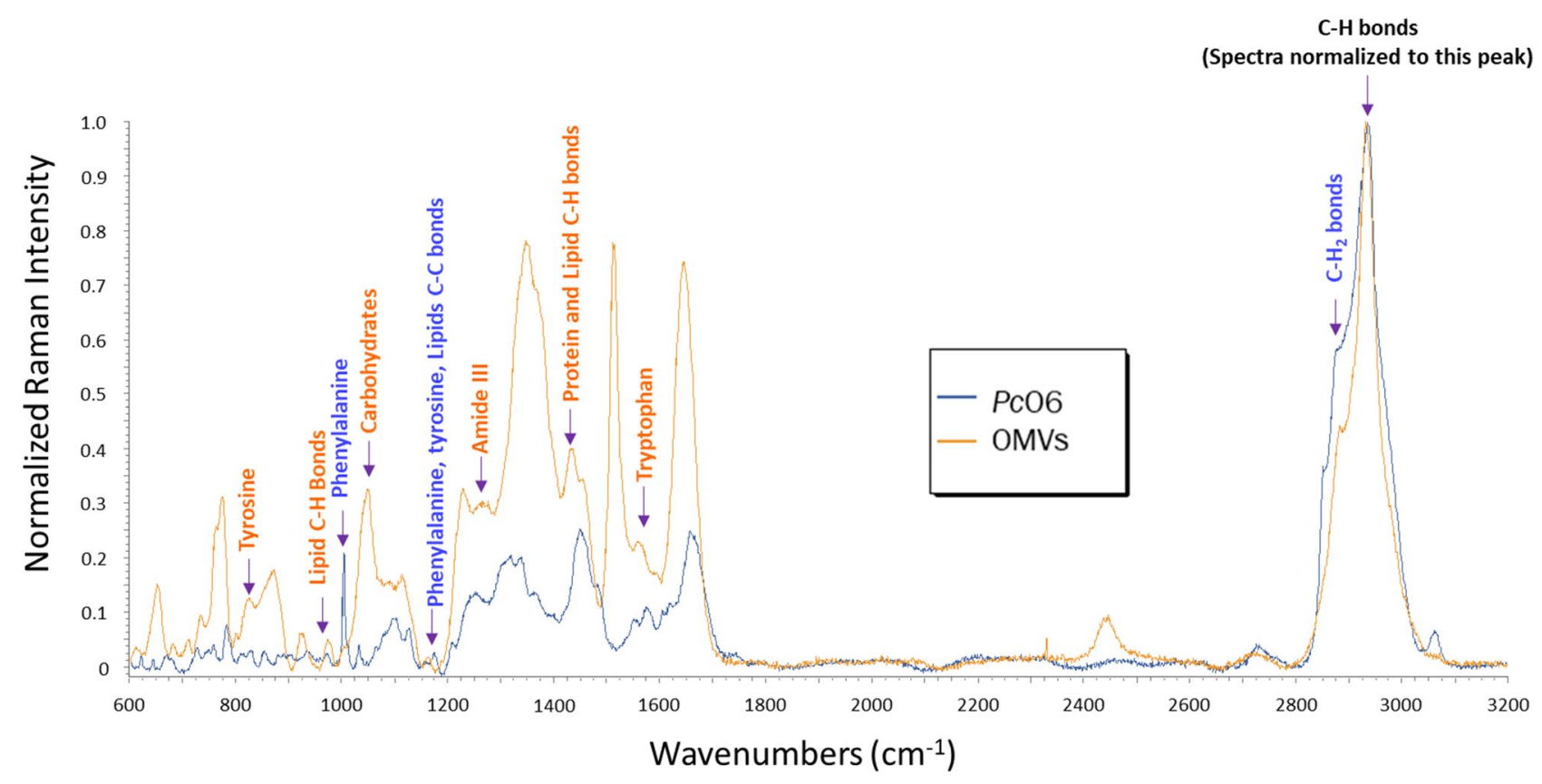

Figure 6. Comparisons between averaged Raman spectra of control PcO6 cells and OMVs ( $\mathrm{n}=24$ for $P c \mathrm{O}$, $\mathrm{n}=12$ for OMVs). Peaks that are shared by PcO6 and OMVs Raman spectra are marked with an arrow and labeled with the peak assignment. Text color indicates whether these peaks are higher in PcO6 cells (blue text), or isolated OMVs (orange text). See Supplemental Table S1 for a list of all peak assignments and respective sources.

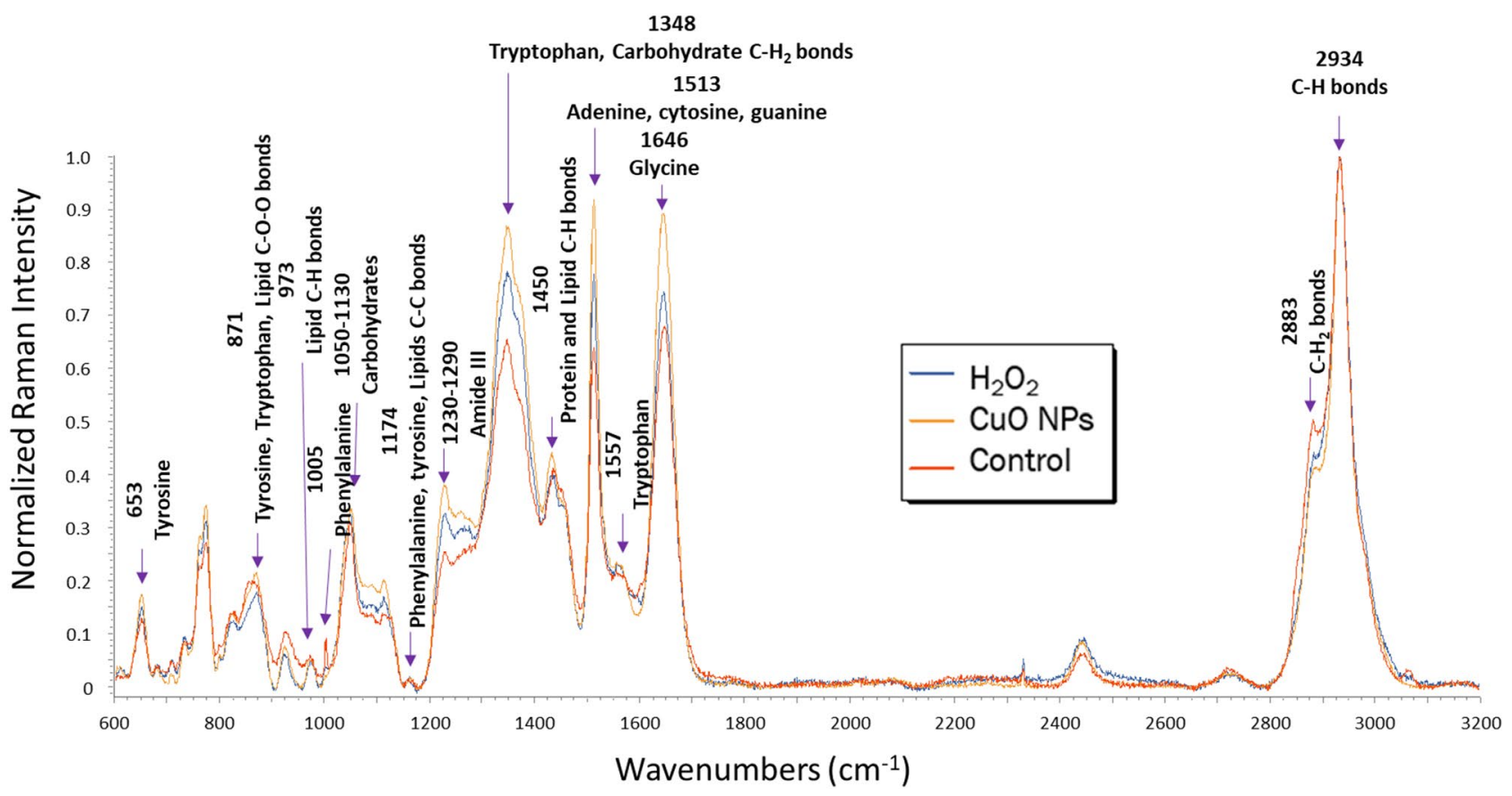

Figure 7. Averaged Raman spectra of OMVs harvested from $\mathrm{PcO} 6$ colonies exposed to $\mathrm{H}_{2} \mathrm{O}_{2}, \mathrm{CuO}$ NPs, or no stressor at all ( 3 replicates with 4 spectra each for a total of $\mathrm{n}=12$ ) from 600 to $3200 \mathrm{~cm}^{-1}$. Differences are seen in normalized peak intensities indicating large differences in relative concentrations of compounds in the OMVs. Notable peak assignments are marked with an arrow and labeled with their respective peak number and peak assignment. For a list of all peak assignments and their sources, see Supplemental Table S1. 


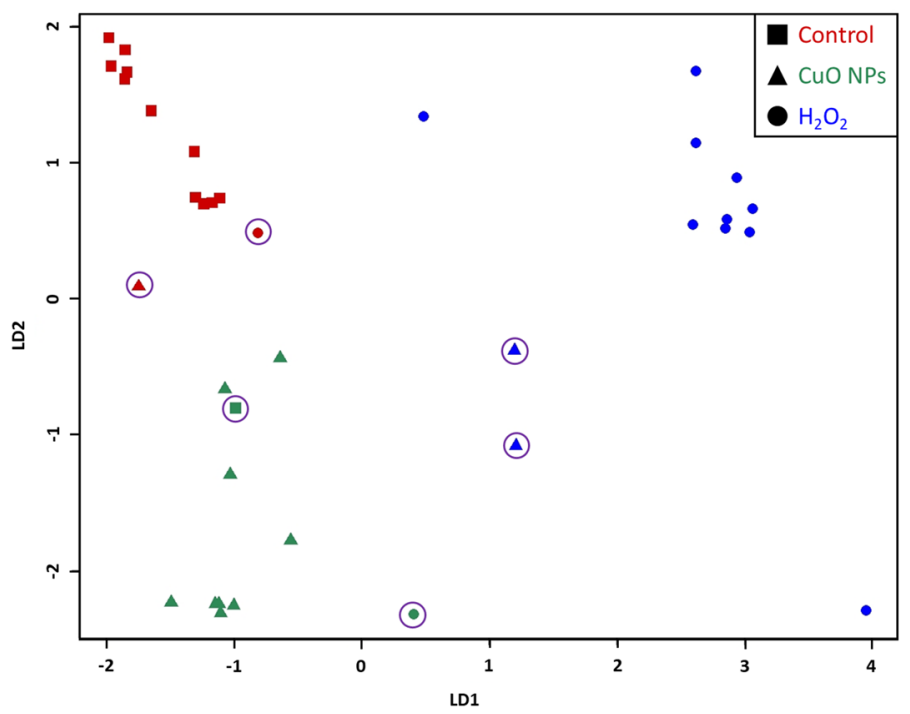

Figure 8. LDA plot of Raman spectra from purified OMVs $(n=12$ for control and CuO NP-induced OMVs and $\mathrm{n}=11$ for $\mathrm{H}_{2} \mathrm{O}_{2}$-induced OMV from three OMV isolations). Data were truncated to $750-1700 \mathrm{~cm}^{-1}$ and $2670-3100 \mathrm{~cm}^{-1}$, where most peaks are located. The shape of the points of the plot indicate the true treatment of each spectrum whereas the color of the point indicates the predicted treatment according to LDA. Misclassified spectra are circled in purple.

\begin{tabular}{|l|l|l|l|l|}
\hline \multicolumn{5}{|l|}{ Confusion matrix of Raman spectra of pure OMVs } \\
\hline \multicolumn{4}{|c|}{} & Predicted treatment \\
\cline { 2 - 6 } & Control & CuO NPs & $\mathrm{H}_{2} \mathrm{O}_{2}$ \\
\hline \multirow{3}{*}{ True treatment } & Control & 11 & 1 & 0 \\
\cline { 2 - 6 } & $\mathrm{CuO} \mathrm{NPs}$ & 1 & 9 & 2 \\
\cline { 2 - 5 } & $\mathrm{H}_{2} \mathrm{O}_{2}$ & 1 & 1 & 10 \\
\hline
\end{tabular}

Table 2. Confusion matrix from LDA plot of Raman spectra given by pure OMVs. Data were truncated to $750-1700 \mathrm{~cm}^{-1}$ and $2670-3100 \mathrm{~cm}^{-1}$, where most peaks are located. LDA of the Raman spectra gave an $83.3 \%$ accuracy indicating that spectra of OMVs are highly dependent on the cellular stressor.

Raman spectroscopy and LDA. Raman spectra of OMVs purified from control and stressed cells showed consistency similar to Raman spectra of control and stressed intact PcO6 cells. Averaged Raman spectra ( $\mathrm{n}=12$ from 3 replicates) from OMVs harvested from cells of all treatments are shown in Fig. 7 differences are seen in the peak intensity of control OMVs and those harvested from PcO6 exposed to $\mathrm{CuO}$ NPs and $\mathrm{H}_{2} \mathrm{O}_{2}$, most notably: (a) $1646 \mathrm{~cm}^{-1}$, glycine; (b) $1513 \mathrm{~cm}^{-1}$, adenine, cytosine, and guanine; and (c) $1348 \mathrm{~cm}^{-1}$, adenine, guanine, tyrosine, and tryptophan. For these peaks, spectra of OMVs from $\mathrm{CuO}$ NP-treated PcO6 had the highest intensity, followed by OMVs from $\mathrm{H}_{2} \mathrm{O}_{2}$-treated $\mathrm{PcO} 6$ then OMVs of control cells.

LDA results of the broad portion of the spectra $\left(750-1700 \& 2670-3100 \mathrm{~cm}^{-1}\right)$ showed a $83.3 \%$ accuracy for pure OMVs from all treatments with several misclassified spectra in each treatment (LDA plot shown in Fig. 8, LDA confusion matrix shown in Table 2). Narrower portions of the spectra were also examined with LDA (Supplemental Fig. S6). Much like the LDA examination of PcO6 spectra, LDA of different portions of the OMV spectra showed differences in the grouping on LDA plots. However, the accuracy of the algorithms did not vary greatly between the spectra portions ( $83-89 \%$ accuracy). Five of the six spectra that were misclassified in LDA of the broader spectra were misclassified in most or all of the narrower portions. The LDA plots of these narrower portions control spectra were far removed from the spectra of the other treatments. In contrast, the spectra of OMVs harvested from $\mathrm{H}_{2} \mathrm{O}_{2}$-treated and $\mathrm{CuO}$ NP-treated cells tended to be grouped apart as well though with a large intermingled section between them that contained many of the misclassified spectra.

Biochemical assays were also used to measure the LPS and protein content of OMVs. LPS content (average of $15.6 \pm 2.7$ endotoxin units $(\mathrm{EU}) / \mathrm{mL}$ solution), which should correlate with OMV number, increased slightly in $\mathrm{H}_{2} \mathrm{O}_{2}$-induced OMVs (Supplemental Fig. S5a). This result matches literature sources that OMV production is increased in response to stress, including ROS stress ${ }^{21,27,28}$. Protein content (average of $23.3 \pm 13.4 \mu \mathrm{g} / \mathrm{mL}$ solution) of OMVs was uncorrelated with cellular stressor and trial (Supplemental Fig. S5b) even when normalized to the LPS content (Supplemental Fig. S5c). 


\section{Discussion}

DLS and AFM measurements showed that OMV sizes were highly polydisperse in size regardless of the cellular stressor. Differing OMV diameter according to the analysis method has been reported in the literature ${ }^{67}$, likely due to differences in OMV aggregation and/or hydration. Aggregation of OMVs observed in AFM and SEM images may be due to outer membrane surface features similar to those involved in adhesion for intact cells ${ }^{69}$. Extracellular biomolecules within the biofilm matrix, which include proteins, polysaccharides, and eDNA ${ }^{70}$, may also bind to OMVs and cause this aggregation. Similar OMV aggregation was observed in studies of OMVs produced by Neisseria lactamica by Gorringe et al. $^{71}$. The researchers observed that numerous large OMV aggregates occurred at $\mathrm{pH} 7.0$ with fewer aggregates occurring at $\mathrm{pH}$ 8.0, implying that many OMV surface proteins reached an isoelectric equilibrium at this higher $\mathrm{pH}$, thus reducing the number of OMV aggregates. LPS charge may also be altered by environmental $\mathrm{pH}$, influencing electrostatic and steric barriers to agglomeration.

OMV aggregation may be counterproductive to signaling and similar OMV roles, however, OMV assembly may contribute to the assembly of scaffolds to create and support the biofilm matrix. OMVs produced by biofilm Myxococcus xanthus cells form chains that tether biofilm cells together ${ }^{72}$. Xyllela fastidiosa uses OMV aggregates to mediate surface adhesion, either promoting or preventing biofilm formation by the bacterium ${ }^{17}$. PcO6 is a strong biofilm former ${ }^{41}$ and OMV release by this bacterium may promote its aggressive colonization of plant roots during adhesion and biofilm formation as patches on the plant $\operatorname{root}^{40}$.

This work established that Raman spectroscopy coupled with LDA was a reliable method for characterization of OMV content; the creation of Raman peak libraries (such as Supplemental Table S1 and references ${ }^{73-76}$ ) is valuable in assigning structural changes to cells under different exposures. In this study, LDA was particularly important as Raman spectra of stressed PcO6 cells did not have different peaks from those of control cells, only peak intensities differed. This same pattern occurred for OMVs isolated from stressed and control cells.

To examine what Raman bands were most heavily weighted during LDA grouping calculations, LDA was also performed on smaller spectral regions (Supplemental Fig. S4). For the spectra of PcO6 cells, it appears that LDA is primarily grouped based on peak differences in the range of $750-1700 \mathrm{~cm}^{-1}$. The $1400-1500 \mathrm{~cm}^{-1}$ and $1500-1700 \mathrm{~cm}^{-1}$ regions were especially unique for $\mathrm{H}_{2} \mathrm{O}_{2}$ and $\mathrm{CuO} N P$ treatments, respectively. LDA of these regions yielded distinct groupings with few miscalculations. For the OMV spectra, the LDA algorithm primarily converged on the $750-1700 \mathrm{~cm}^{-1}$ range as well. However, LDA of narrower spectral portions within this range did not improve LDA results, indicating that LDA groupings of OMV spectra are less reliant on single peaks and regions than LDA groupings of $P c \mathrm{O} 6$ cells.

Comparing Raman spectra of intact PcO6 cells and isolated OMVs, it is clear that certain PcO6 cell components are enriched while others are excluded in OMVs, which agrees with studies of other Gram-negative bacteria $^{8,77}$. The decreased peak intensity of $\mathrm{H}_{2} \mathrm{O}_{2}$-treated $\mathrm{PcO}$ cells is likely because unsaturated lipids react with $\mathrm{H}_{2} \mathrm{O}_{2}$ to form lipid peroxides and reactive aldehydes ${ }^{78}$. The fact that the same peaks are affected in $\mathrm{CuO}$ NP-stressed $\mathrm{PcO} 6$ cells likely indicates that ROS are formed in cells as a response to $\mathrm{CuO} \mathrm{NP}$ stress, a cell response that contributes to the dose-dependent bactericidal activity of $\mathrm{CuO} \mathrm{NPs}^{79}$. The relative greater content of unsaturated lipids in OMVs harvested from these stressed cells compared to OMVs produced by control cells could relate to changes in membrane integrity of cells under stress.

Also notable is the high amount of nucleic acids in OMVs compared to whole biofilm PcO6 cells, implicating the potential role of OMVs to transport DNA and/or RNA in PcO6 biofilms. RNA in OMVs has been reported in the forms of ribosomal RNA, mRNA, and small RNAs ${ }^{80}$. OMVs released by $P$. aeruginosa may contain plasmid $\mathrm{DNA}^{12}$, coding chromosomal DNA ${ }^{5}$, or noncoding $\mathrm{eDNA}^{37}$. These nucleic acids extend proposed OMV roles in cell-to-cell communication to both gene and transcription levels assuming OMV contents are taken up by live cells. OMVs of $P$. aeruginosa contain chromosomal DNA encoding genes related to bacterial survival under stress conditions ${ }^{5}$. The eDNA is an important part of the biofilm matrix ${ }^{45}$ and is involved in adhesion to surfaces, aggregation of bacterial cells, and the exchange of genetic information ${ }^{70}$. In H. pylori, eDNA was observed on OMV surfaces, with suggested roles in OMV aggregation and cell-to-cell binding ${ }^{6}$ including within the biofilm matrix ${ }^{72}$.

The biochemical assays confirmed the presence of protein, LPS, and nucleic acids in the OMVs from PcO6 that are indicated from the Raman spectral peaks. The inability of these assays to discriminate among OMVs according to the cellular stressor is unsurprising: OMVs are chemically heterogeneous in nature ${ }^{6,16,68}$ due to the multiple potential mechanisms and pathways that lead to OMV formation ${ }^{11,81,82}$. The presence of LPS, lipoproteins, and DNA in OMVs is significant because these are among the structures known as MAMPs and DAMPs that induce plant innate resistance ${ }^{35}$. Thus, the contents of the OMVs released from $P c \mathrm{O} 6$ cells may be implicated in the induction of systemic resistance observed in plants with roots colonized with PcO6.

The findings of OMV production from the plant-beneficial microbe, $P c \mathrm{O} 6$, and the changes in their composition with NP and ROS exposure revealed features that influence plant and bacterial responses in the rhizosphere. The nature of the charge on the OMV surfaces and the eDNA content might affect biofilm formation. Proteins such as catalase found in OMVs from other bacteria ${ }^{28}$ potentially protect the bacterial cell from oxidative damage. DNA and RNA release through OMVs could affect plant gene expression. These bacterial nucleic acids, along with other confirmed MAMPs such as LPS, carried by OMVs, could induce plant resilience to stress.

In summary, research into the heterogeneous nature and multiple roles of OMVs is supported by applying sensitive techniques such as Raman spectroscopy supported by appropriate analyzation algorithms such as LDA. In this study, these methods were able to chemically characterize purified OMVs and categorize these vesicles based on two cellular stressors relevant to the soil environment of the plant health-promoting bacterium, PcO6. The ability to differentiate $\mathrm{H}_{2} \mathrm{O}_{2}$-induced and $\mathrm{CuO}$ NP-induced OMVs reveals that these stressors do not merely induce OMV production. Rather, $\mathrm{PcO} 6$ responds to these stressors with changes in OMV contents and composition. The construction of an OMV Raman peak assignment library presented here provides a baseline for future analyses by our group and others. 


\section{Methods}

Bacterial growth conditions. $\quad P c \mathrm{O} 6$ stocks were kept at $-80{ }^{\circ} \mathrm{C}$ in $15 \%$ glycerol and thawed before use. PcO6 biofilms were grown at $22{ }^{\circ} \mathrm{C}$ on minimal medium $\left(\mathrm{K}_{2} \mathrm{HPO}_{4}-10.5 \mathrm{~g} / \mathrm{L}, \mathrm{KH}_{2} \mathrm{PO}_{4}-4.5 \mathrm{~g}\right.$, $\mathrm{Na}^{\star}$ citrate ${ }^{\star} 2 \mathrm{H}_{2} \mathrm{O}-0.5 \mathrm{~g} / \mathrm{L},\left(\mathrm{NH}_{4}\right)_{2} \mathrm{SO}_{4}-1 \mathrm{~g} / \mathrm{L}$, sucrose $-2 \mathrm{~g} / \mathrm{L}$, anhydrous $\left.\mathrm{MgSO}_{4}-0.125 \mathrm{~g} / \mathrm{L}\right) 2 \%$ agar plates $(15 \times 100 \mathrm{~mm})$ for $48 \mathrm{~h}$ to a confluent lawn.

PcO6 biofilms were also grown on hollow fiber membranes for SEM imaging ${ }^{41}$. Hollow fiber membranes were inoculated with $2 \mu \mathrm{L}$ PcO6 suspended in sterile double distilled $\mathrm{H}_{2} \mathrm{O}\left(\mathrm{ddH}_{2} \mathrm{O}\right)$ (resistance $\left.>18 \mathrm{M} \Omega \mathrm{cm}\right)$ at a concentration of $10^{6}$ colony forming units (CFUs) $/ \mathrm{mL}$, draped across wells with liquid minimal medium, and allowed to grow at $22^{\circ} \mathrm{C}$ for $28 \mathrm{~h}$.

Abiotic stressor preparations. Sterile $\mathrm{ddH}_{2} \mathrm{O}$ was used as the control treatment. Commercial CuO NPs (nominal size $<100 \mathrm{~nm}, 99.95 \%$ purity) were obtained from American Elements as a nanopowder and stored protected from light. NP size distribution and agglomeration profiles were confirmed with scanning electron microscopy (FEI Quanta FEG 650) (Supplemental Fig. S7). NP elemental composition was determined by scanning electron microscopy with energy-dispersive X-ray spectroscopy using an X-Max Detector (Oxford Instruments). NP stress used $\mathrm{CuO}$ NPs suspended in sterile $\mathrm{ddH}_{2} \mathrm{O}(30 \mathrm{mg} \mathrm{Cu}$ from CuO NPs/L) through sonication (Q500, QSonica LLC) for 10 min with an alternating $10 \mathrm{~s}$ on/off cycle at 25\% amplitude. The ROS stress was 3\% $\mathrm{H}_{2} \mathrm{O}_{2}(\mathrm{v} / \mathrm{v})$.

Treatments of PcO6 biofilm cells before OMV isolation. The confluent lawns of $P c \mathrm{O} 6$ biofilm cells on minimal medium agar were treated by flooding with $10 \mathrm{~mL}$ of $\mathrm{ddH}_{2} \mathrm{O}, \mathrm{H}_{2} \mathrm{O}_{2}$, or CuO NPs, added in $1 \mathrm{~mL}$ aliquots. These conditions were maintained for $60 \mathrm{~min}$, during which time the cells detached from the surface and became suspended in the liquid. CFUs were counted with serial dilutions on LB $2 \%$ agar petri dishes to check the effect of stressors on cell viability. CuO NPs had no significant effect on the ability of PcO6 to generate colonies on plate medium whereas $\mathrm{H}_{2} \mathrm{O}_{2}$ exposure reduced colonies $<10 \%$.

Isolating and purifying outer membrane vesicles. OMVs were isolated from PcO6 cells using a method adapted from Zhou et al. ${ }^{83}$. Twenty minimal medium plates with confluent $P c$ O6 lawns (a total surface area of $\left.0.628 \mathrm{~m}^{2}\right)$ were used per treatment to maximize OMV yields for analysis. The cell suspension $(10 \mathrm{~mL} /$ plate for a total of $200 \mathrm{~mL} /$ treatment) was poured from the petri dishes into $50 \mathrm{~mL}$ polypropylene conical tubes and centrifuged $(10,000 \times \mathrm{g}, 20 \mathrm{~min})$ to generate a cell pellet leaving OMVs and other secreted materials in the supernatant. This step also removed $\mathrm{CuO}$ NPs from the solution when this stressor was used. The OMVs were concentrated from the supernatant by ammonium sulfate precipitation. Ammonium sulfate (Mallinckrodt chemicals) was added over the course of two hours ( $240 \mathrm{~g} / \mathrm{L}$ total) at $15 \mathrm{~min}$ intervals to the supernatant, which was left undisturbed at $22^{\circ} \mathrm{C}$ until precipitates formed (anywhere from $2-8 \mathrm{~h}$ ). The precipitates were pelleted by centrifugation $(10,000 \times g, 10 \mathrm{~min})$, resuspended in $1 \mathrm{~mL}$ sterile deionized $\mathrm{H}_{2} \mathrm{O}$, and dialyzed against $\mathrm{ddH}_{2} \mathrm{O}$ for at least $16 \mathrm{~h}$. The solution was sterile filtered $(0.45 \mu \mathrm{m}$, Ultrafree PVDF centrifugal filter units, Beckman Coulter Inc.) to remove any remaining cells or contaminants.

To purify OMVs from flagella, pili, and secondary metabolites (Supplemental Fig. S8), density gradient ultracentrifugation was performed using methods adapted from Chutkan et al. ${ }^{84}$. The crude OMV suspension was mixed with OptiPrep iodixanol gradient medium (Sigma Aldrich) to create a 45\% OptiPrep solution (vol/ vol). A $2 \mathrm{~mL}$ aliquot was loaded into the base of each ultracentrifuge tube (Ultraclear $12.5 \mathrm{~mL}$ centrifuge tube, Beckman Coulter) and covered sequentially with $2 \mathrm{~mL}$ layers of 40, 35, 30, 25, and 20\% OptiPrep before centrifugation $\left(212,000 \times g, 3 \mathrm{~h}, 4^{\circ} \mathrm{C}\right)$ (Optima LE-80 K Centrifuge, Beckman). Aliquots of $1 \mathrm{~mL}$ were collected from the top of the gradient in a cold room to minimize diffusion. OMV-containing fractions, the top $1 \mathrm{~mL}$ of each tube, were pooled from each treatment, diluted at least 10 times with sterile deionized $\mathrm{H}_{2} \mathrm{O}$, loaded into centrifuge tubes (26.3 mL Polycarbonate Bottle with Cap, Beckman Coulter), and centrifuged $(40,000 \times g, 3 \mathrm{~h})$ to pellet the OMVs. The OMV pellet was resuspended in $750 \mu \mathrm{L}$ sterile $\mathrm{ddH}_{2} \mathrm{O}$ and sterile filtered $(0.45 \mu \mathrm{m}$, Ultrafree PVDF centrifugal filter units). The presence of OMVs in the filtrate was confirmed with AFM imaging. Pure OMV preps were stored at $4{ }^{\circ} \mathrm{C}$ until used for Raman spectroscopy, which took place within $48 \mathrm{~h}$ of OMV isolation and purification. Samples were frozen $\left(-20^{\circ} \mathrm{C}\right)$ until used for biochemical assays.

Atomic force microscopy (AFM). AFM was performed on a Nanoscope III Bioscope (Digital Instruments, Inc.) in tapping mode. Budget Sensors-Tap 300AL-G cantilevers with a tip radius of curvature $<10 \mathrm{~nm}$, length of $125 \mu \mathrm{m}$, width of $30 \mu \mathrm{m}$, thickness of $4 \mu \mathrm{m}$, and a $40 \mathrm{~N} / \mathrm{m}$ force constant were employed. Images were collected at $256 \times 256$ resolution and $1 \mathrm{~Hz}$ over a range of scan sizes and scan angles. For intact biofilm PcO6 cells, a sample of the bacterial lawn on a sterile inoculation loop was smeared on a clean glass slide and immediately imaged. For OMVs, $20 \mu \mathrm{L}$ purified OMV suspension was pipetted onto a clean glass slide, allowed to dry, and immediately imaged. OMV diameter was determined using the horizontal distance and the vertical distance in the line cut feature in the Nanoscope software (Supplemental Fig. S9). Four images were used for each treatment with a total of 100 OMVs measured per treatment.

Scanning electron microscopy (SEM). SEM was performed with an FEI Quanta FEG 650 equipped with an Oxford X-Max EDS housed in the Microscopy Core Facility at Utah State University. Hollow fiber membranes with $\mathrm{PcO}$ biofilms were dipped in sterile distilled $\mathrm{H}_{2} \mathrm{O}$, fixed in methanol for $10 \mathrm{~min}$, and dried in two $10 \mathrm{~min}$ bath of $100 \%$ ethanol. Samples were critical point dried and sputter coated in an $\mathrm{Au} / \mathrm{Pd}$ coat. Images were captured under high vacuum. Purified OMVs were pipetted onto a clean substrate, fixed with $2.5 \%$ glutaralde- 
hyde, dehydrated using two 5 min washes of increasing ethanol concentrations (50, 70, \& 95\%) followed by three 15 min washes with $100 \%$ ethanol. Samples were imaged under high vacuum without coatings.

Dynamic light scattering. DLS measurements were performed on a DynaPro NanoStar (Wyatt Technology Corporation, Santa Barbara, CA) employing Dynamics Software (version 7.0.3, Wyatt Technology Corporation, Santa Barbara, CA) and a $658 \mathrm{~nm}$ laser. The purified OMV suspensions were diluted 1:10 in sterile deionized water, and $70 \mu \mathrm{L}$ was transferred to DLS cuvettes. The intensity autocorrelation function (see Supplemental Fig. S10 for autocorrelation graphs) was used to calculate a hydrodynamic diameter based on the Stokes-Einstein equation using a regularization method employed in the software.

Raman spectroscopy and linear discriminant analysis (LDA). To examine the intact cells, confluent $P c \mathrm{O} 6$ lawns from two minimal medium plates with or without the stress treatments were centrifuged from solution $(14,000 \times g, 10 \mathrm{~min})$, and resuspended in $1 \mathrm{~mL}$ sterile, deionized $\mathrm{H}_{2} \mathrm{O}$. This process was repeated two additional times to remove stressors. After the third centrifugation, PcO6 cells were resuspended in $200 \mu \mathrm{L}$ sterile, deionized $\mathrm{H}_{2} \mathrm{O}$. A total of $6 \mathrm{PcO} 6$ replicates were performed per treatment. The majority of OMVs, cell secretions, and other cell debris remained in the supernatant which was discarded after each centrifugation. A 10 $\mu \mathrm{L}$ aliquot of the PcO6 suspension was pipetted onto aluminum tape affixed to a clean glass microscope slide and allowed to dry. For OMVs, no additional preparation was needed for Raman spectroscopy after isolation and purification steps. A total of 3 isolations were performed with each treatment. Twenty $\mu \mathrm{L}$ purified OMV suspension was pipetted onto aluminum tape affixed to a clean glass microscope slide and allowed to dry.

Raman spectra were obtained using a Renishaw inVia Raman microscope with a $633 \mathrm{~nm}$ laser, $1200 \mathrm{~g} /$ $\mathrm{mm}$ grating, and $14 \mathrm{~mW}$ laser power. Spectra were obtained over a $30 \mathrm{~s}$ acquisition time with a wavenumber range of $200-3200 \mathrm{~cm}^{-1}$, with 3 accumulations per spectrum. Four spectra were captured per treatment during each replicate for a total of $n=24$ for PcO6 spectra and $n=12$ for OMV spectra. Spectrogryph ${ }^{85}$ was used to visualize spectra, obtain peak numbers, and average spectra. LDA of spectra was performed with $\mathrm{R}$ following background subtraction (WiRE 4.1), removal of cosmic rays (WiRE 4.1), and normalization of spectra (R). Data were truncated to $750-1700 \mathrm{~cm}^{-1}$ and $2670-3100 \mathrm{~cm}^{-1}$ for broad-spectrum analysis. PcO6 cell spectra were further truncated to $750-1700 \mathrm{~cm}^{-1}, 2670-3100 \mathrm{~cm}^{-1}, 700-950 \mathrm{~cm}^{-1}, 950-1200 \mathrm{~cm}^{-1}, 1200-1400 \mathrm{~cm}^{-1}$, $1400-1500 \mathrm{~cm}^{-1}$, or $1500-1700 \mathrm{~cm}^{-1}$ for additional examination with LDA. OMV spectra were further truncated to $750-1700 \mathrm{~cm}^{-1}, 2670-3100 \mathrm{~cm}^{-1}, 1000-1200 \mathrm{~cm}^{-1}, 1200-1500 \mathrm{~cm}^{-1}, 1500-1600 \mathrm{~cm}^{-1}$, or $1500-1600 \mathrm{~cm}^{-1}$ for additional examination with LDA.

Micro-bicinchoninic acid (micro-BCA) assay. OMV protein content was quantified with a Pierce micro-BCA assay kit (Thermo Scientific). Frozen OMV samples were thawed and prepared according to the manufacturer's instructions and absorbance was read at $562 \mathrm{~nm}$ (Synergy HT, BioTek Instruments Inc.) with appropriate bovine serum albumin standards from the manufacturer with concentrations of 0 to $200 \mu \mathrm{g}$ protein/ $\mathrm{mL}$. Duplicates were run for each standard and sample.

Lipopolysaccharide (LPS) quantification. OMV LPS content was quantified with a Pierce Endotoxin Quantification Kit (Thermo Scientific). Frozen samples were thawed and prepared according to the manufacturer's instructions and absorbance was read at $405 \mathrm{~nm}$ (Synergy HT, BioTek Instruments Inc.) with LPS standards from Escherichia coli supplied by the manufacturer in the range of 0.1 to 1 Endotoxin Units (EU)/mL. Duplicates were run for each standard and sample.

260/280 absorption ratio. The nucleic acid to protein ratio was determined based on the 260/280 UVabsorption ratio. Frozen samples were thawed and $2 \mu \mathrm{L}$ of each sample was pipetted into wells of a Take 3 MicroVolume plate (BioTek Instruments Inc.) and absorbance was read at 260 and $280 \mathrm{~nm}$ (Synergy HT, BioTek Instruments Inc.). Standards of bovine serum albumin $(40 \mu \mathrm{g} / \mathrm{mL})$ from a micro-BCA assay kit (Thermo Scientific) and double-stranded DNA $(100 \mu \mathrm{g} / \mathrm{mL})$ from a PicoGreen DNA quantification kit (Thermo Scientific) were also run. Duplicates were run for each sample and standard.

\section{Data availability}

The datasets generated during this study are available from the corresponding authors on appropriate request.

Received: 24 July 2020; Accepted: 13 November 2020

Published online: 04 December 2020

\section{References}

1. Li, Z., Clarke, A. J. \& Beveridge, T. J. Gram-negative bacteria produce membrane vesicles which are capable of killing other bacteria. J. Bacteriol. 180, 5478-5483 (1998).

2. Yáñez-Mó, M. et al. Biological properties of extracellular vesicles and their physiological functions. J. Extracell. Vesicles 4, 1-60 (2015)

3. Kim, J. H., Lee, J., Park, J. \& Gho, Y. S. Gram-negative and Gram-positive bacterial extracellular vesicles. Semin. Cell Dev. Biol. 40, 97-104 (2015).

4. Schwechheimer, C. \& Kuehn, M. J. Outer-membrane vesicles from Gram-negative bacteria: biogenesis and functions. Nat. Rev. Microbiol. 13, 605-619 (2015).

5. Bitto, N. J. et al. Bacterial membrane vesicles transport their DNA cargo into host cells. Sci. Rep. 7, 1-11 (2017)

6. Grande, R. et al. Helicobacter pylori ATCC 43629/NCTC 11639 outer membrane vesicles (OMVs) from biofilm and planktonic phase associated with extracellular DNA (eDNA). Front. Microbiol. 6, 1-10 (2015). 
7. Koeppen, K. et al. A novel mechanism of host-pathogen interaction through sRNA in bacterial outer membrane vesicles. PLoS Pathog. 12, 10 (2016).

8. Bonnington, K. E. \& Kuehn, M. J. Protein selection and export via outer membrane vesicles. Biochim. Biophys. Acta Mol. Cell Res. 1843, 1612-1619 (2014).

9. Horstman, A. L. \& Kuehn, M. J. Enterotoxigenic Escherichia coli secretes active heat-labile enterotoxin via outer membrane vesicles. J. Biol. Chem. 275, 12489-12496 (2000).

10. Bomberger, J. M. et al. Long-distance delivery of bacterial virulence factors by Pseudomonas aeruginosa outer membrane vesicles. PLoS Pathog. 5, 10 (2009).

11. Ellis, T. N. \& Kuehn, M. J. Virulence and immunomodulatory roles of bacterial outer membrane vesicles. Microbiol. Mol. Biol. Rev. 74, 81-94 (2010).

12. Renelli, M., Matias, V., Lo, R. Y. \& Beveridge, T. J. DNA-containing membrane vesicles of Pseudomonas aeruginosa PAO1 and their genetic transformation potential. Microbiology 150, 2161-2169 (2004).

13. Berleman, J. \& Auer, M. The role of bacterial outer membrane vesicles for intra- and interspecies delivery. Environ. Microbiol. 15, 347-354 (2013).

14. Bauman, S. J. \& Kuehn, M. J. Pseudomonas aeruginosa vesicles associate with and are internalized by human lung epithelial cells. BMC Microbiol. 9, 1-12 (2009).

15. Beveridge, T. J. Structures of Gram-negative cell walls and their derived membrane vesicles. J. Bacteriol. 181, 4725-4733 (1999).

16. Schooling, S. R. \& Beveridge, T. J. Membrane vesicles: an overlooked component of the matrices of biofilms. J. Bacteriol. 188, 5945-5957 (2006).

17. Ionescu, M. et al. Xyllela fastidiosa outer membrane vesicles modulate plant colonization by blocking attachment to surfaces. Proc. Natl. Acad. Sci. 111, E3910-E3918 (2014).

18. Yonezawa, H. et al. Outer membrane vesicles of Helicobacter pylori TK1402 are involved in biofilm formation. BMC Microbiol. 9 , $1-12(2009)$.

19. Mashburn, L. M. \& Whiteley, M. Membrane vesicles traffic signals and facilitate group activities in a prokaryote. Nature 437, $422-425$ (2005).

20. Mashburn-Warren, L. et al. Interaction of quorum signals with outer membrane lipids: Insights into prokaryotic membrane vesicle formation. Mol. Microbiol. 69, 491-502 (2008).

21. van de Waterbeemd, B. et al. Cysteine depletion causes oxidative stress and triggers outer membrane vesicle release by Neisseria meningitidis; implications for vaccine development. PLoS ONE 8, e54231 (2013).

22. McBroom, A. J. \& Kuehn, M. J. Release of outer membrane vesicles by Gram-negative bacteria is a novel envelope stress response. Mol. Microbiol. 63, 545-558 (2007).

23. Haurat, M. F., Elhenawy, W. \& Feldman, M. F. Prokaryotic membrane vesicles: new insights on biogenesis and biological roles. Biol. Chem. 396, 95-109 (2015).

24. Manning, A. J. \& Kuehn, M. J. Contribution of bacterial outer membrane vesicles to innate bacterial defense. BMC Microbiol. 11, $258(2011)$.

25. Kadurugamuwa, J. L. \& Beveridge, T. J. Bacteriolytic effect of membrane vesicles from Pseudomonas aeruginosa on other bacteria including pathogens: conceptually new antibiotics. J. Bacteriol. 178, 2767-2774 (1996).

26. Berleman, J. E. et al. The lethal cargo of Myxococcus xanthus outer membrane vesicles. Front. Microbiol. 5, 1-11 (2014).

27. MacDonald, I. A. \& Kuehn, M. J. Stress-induced outer membrane vesicle production by Pseudomonas aeruginosa. J. Bacteriol. 195, 2971-2981 (2013).

28. Lekmeechai, S. et al. Helicobacter pylori outer membrane vesicles protect the pathogen from reactive oxygen species of the respiratory burst. Front. Microbiol. 9, 1-6 (2018).

29. Schaar, V., Nordström, T., Mörgelin, M. \& Riesbeck, K. Moraxella catarrhalis outer membrane vesicles carry $\beta$-lactamase and promote survival of Streptococcus pneumoniae and Haemophilus influenzae by inactivating amoxicillin. Antimicrob. Agents Chemother. 55, 3845-3853 (2011).

30. Wang, W., Chanda, W. \& Zhong, M. The relationship between biofilm and outer membrane vesicles: a novel therapy overview. FEMS Microbiol. Lett. 362, 1-6 (2015).

31. Katsir, L. \& Bahar, O. Bacterial outer membrane vesicles at the plant-pathogen interface. PLOS Pathog. 13, e1006306 (2017).

32. Bahar, O. et al. Bacterial outer membrane vesicles induce plant immune responses. Mol. Plant Microbe Interact. 29, 374-384 (2016).

33. Schikora, A., Schenk, S. T. \& Hartmann, A. Beneficial effects of bacteria-plant communication based on quorum sensing molecules of the N-acyl homoserine lactone group. Plant Mol. Biol. 90, 605-612 (2016).

34. Hughes, D. T. \& Sperandio, V. Inter-kingdom signalling: communication between bacteria and their hosts. Nat. Rev. Microbiol. 6, $111-120$ (2008).

35. Choi, H. W. \& Klessig, D. F. DAMPs, MAMPs, and NAMPs in plant innate immunity. BMC Plant Biol. 16, 1-10 (2016).

36. Ellis, T. N., Leiman, S. A. \& Kuehn, M. J. Naturally produced outer membrane vesicles from Pseudomonas aeruginosa elicit a potent innate immune response via combined sensing of both lipopolysaccharide and protein components. Infect. Immun. 78, 3822-3831 (2010).

37. Whitchurch, C. B., Tolker-Nielsen, T., Ragas, P. C. \& Mattick, J. S. Extracellular DNA required for bacterial biofilm formation. Science 295, 1487 (2002).

38. Spencer, M. et al. Induced defence in tobacco by Pseudomonas chlororaphis strain O6 involves at least the ethylene pathway. Physiol. Mol. Plant Pathol. 63, 27-34 (2003).

39. Kim, J. S., Kim, Y. H., Park, J. Y., Anderson, A. J. \& Kim, Y. C. The global regulator GacS regulates biofilm formation in Pseudomonas chlororaphis O6 differently with carbon source. Can. J. Microbiol. 60, 133-138 (2014).

40. Jacobson, A. et al. Interactions between a plant probiotic and nanoparticles on plant responses related to drought tolerance. Ind. Biotechnol. 14, 148-156 (2018).

41. Bonebrake, M. et al. Biofilms benefiting plants exposed to $\mathrm{ZnO}$ and $\mathrm{CuO}$ nanoparticles studied with a root-mimetic hollow fiber membrane. J. Agric. Food Chem. 66, 6619-6627 (2018).

42. Anderson, A. J. \& Kim, Y. C. Biopesticides produced by plant-probiotic Pseudomonas chlororaphis isolates. Crop Prot. 105, 62-69 (2018).

43. Cho, S. M. et al. 2R,3R-Butanediol, a bacterial volatile produced by Pseudomonas chlororaphis O6, is involved in induction of systemic tolerance to drought in Arabidopsis thaliana. Mol. Plant-Microbe Interact. 21, 1067-1075 (2008).

44. Timmusk, S. et al. Sfp-type PPTase inactivation promotes bacterial biofilm formation and ability to enhance wheat drought tolerance. Front. Microbiol. 6, 1-13 (2015).

45. Costa, O. Y. A., Raaijmakers, J. M. \& Kuramae, E. E. Microbial extracellular polymeric substances - ecological functions and impact on soil aggregation. Front. Microbiol. 9, 1636 (2018).

46. Dimkpa, C. O. et al. Nanospecific inhibition of pyoverdine siderophore production in Pseudomonas chlororaphis $\mathrm{O} 6$ by $\mathrm{CuO}$ nanoparticles. Chem. Res. Toxicol. 25, 1066-1074 (2012).

47. Gade, A. et al. Ag nanoparticles generated using bio-reduction and -coating cause microbial killing without cell lysis. Biometals 29, 211-223 (2016).

48. Liu, R. \& Lal, R. Potentials of engineered nanoparticles as fertilizers for increasing agronomic productions. Sci. Total Environ. 514, $131-139$ (2015). 
49. Sekhon, B. S. Nanotechnology in agri-food production: an overview. Nanotechnol. Sci. Appl. 7, 31-53 (2014).

50. Khan, M. N., Mobin, M., Abbas, Z. K., AlMutairi, K. A. \& Siddiqui, Z. H. Role of nanomaterials in plants under challenging environments. Plant Physiol. Biochem. 110, 194-209 (2017).

51. Anderson, A. J., McLean, J. E., Jacobson, A. R. \& Britt, D. W. CuO and $\mathrm{ZnO}$ nanoparticles modify interkingdom cell signaling processes relevant to crop production. J. Agric. Food Chem. https://doi.org/10.1021/acs.jafc.7b01302 (2017).

52. Yang, K. Y. et al. Remodeling of root morphology by $\mathrm{CuO}$ and $\mathrm{ZnO}$ nanoparticles: effects on drought tolerance for plants colonized by a beneficial pseudomonad. Botany 96, 175-186 (2018).

53. Timmusk, S., Seisenbaeva, G. \& Behers, L. Titania (TiO2) nanoparticles enhance the performance of growth-promoting rhizobacteria. Sci. Rep. 8, 1-13 (2018).

54. Van Aken, B. Gene expression changes in plants and microorganisms exposed to nanomaterials. Curr. Opin. Biotechnol. 33, 206-219 (2015).

55. Dimkpa, C. O., Mclean, J. E., Britt, D. W. \& Anderson, A. J. CuO and $\mathrm{ZnO}$ nanoparticles differently affect the secretion of fluorescent siderophores in the beneficial root colonizer, Pseudomonas chlororaphis O6. Nanotoxicology 6, 635-642 (2012).

56. Dimkpa, C. O. et al. Production of indole-3-acetic acid via the indole-3-acetamide pathway in the plant-beneficial bacterium Pseudomonas chlororaphis $\mathrm{O} 6$ is inhibited by $\mathrm{ZnO}$ nanoparticles but enhanced by $\mathrm{CuO}$ nanoparticles. Appl. Environ. Microbiol. 78, 1404-1410 (2012).

57. Marslin, G., Sheeba, C. J. \& Franklin, G. Nanoparticles alter secondary metabolism in plants via ROS burst. Front. Plant Sci. 8, 1-8 (2017).

58. Adams, J. et al. $\mathrm{Cu}$ from dissolution of $\mathrm{CuO}$ nanoparticles signals changes in root morphology. Plant Physiol. Biochem. 110, 108-117 (2017).

59. Momen-Heravi, F. et al. Alternative methods for characterization of extracellular vesicles. Front. Physiol. 3, 1-8 (2012).

60. Swain, R. J. \& Stevens, M. M. Raman microspectroscopy for non-invasive biochemical analysis of single cells. Biochem. Soc. Trans. 35, 544-549 (2007).

61. Huang, W. E., Li, M., Jarvis, R. M., Goodacre, R. \& Banwart, S. A. Shining light on the microbial world the application of Raman microspectroscopy. Adv. Appl. Microbiol. 70, 153-186 (2010).

62. Harz, M., Rösch, P. \& Popp, J. Vibrational spectroscopy-A powerful tool for the rapid identification of microbial cells at the singlecell level. Cytom. Part A 75, 104-113 (2009).

63. Hanson, C., Bishop, M. M., Barney, J. T. \& Vargis, E. Effect of growth media and phase on Raman spectra and discrimination of mycobacteria. J. Biophotonics https://doi.org/10.1002/jbio.201900150 (2019).

64. Huefner, A. et al. Characterization and visualization of vesicles in the endo-lysosomal pathway with surface-enhanced Raman spectroscopy and chemometrics. ACS Nano 10, 307-316 (2016).

65. Krafft, C. et al. A specific spectral signature of serum and plasma-derived extracellular vesicles for cancer screening. Nanomed. Nanotechnol. Biol. Med. 13, 835-841 (2016).

66. Tatischeff, I., Larquet, E., Falcón-Pérez, J. M., Turpin, P.-Y. \& Kruglik, S. G. Fast characterisation of cell-derived extracellular vesicles by nanoparticles tracking analysis, cryo-electron microscopy, and Raman tweezers microspectroscopy. J. Extracell. Vesicles 1, 19179 (2012).

67. Kim, S. Y., Khanal, D., Kalionis, B. \& Chrzanowski, W. High-fidelity probing of the structure and heterogeneity of extracellular vesicles by resonance-enhanced atomic force microscopy infrared spectroscopy. Nat. Protoc. 14, 576-593 (2019).

68. Deatheragea, B. L. \& Cookson, B. T. Membrane vesicle release in bacteria, eukaryotes, and archaea: A conserved yet underappreciated aspect of microbial life. Infect. Immun. 80, 1948-1957 (2012).

69. Berleman, J. E., Zemla, M., Remis, J. P. \& Auer, M. Preparation of outer membrane vesicles from Myxococcus xanthus. Bio-Protocol 6, 2 (2016)

70. Flemming, H. C. \& Wingender, J. The biofilm matrix. Nat. Rev. Microbiol. 8, 623-633 (2010).

71. Gorringe, A. et al. The development of a meningococcal disease vaccine based on outer membrane vesicles. Vaccine 23, 2210-2213 (2005).

72. Remis, J. P. et al. Bacterial social networks: structure and composition of Myxococcus xanthus outer membrane vesicle chains. Environ. Microbiol. 16, 598-610 (2014).

73. Sockalingum, G. D. et al. Vibrational spectroscopy as a probe to rapidly detect, identify, and characterize micro-organisms. Biomed. Appl. Raman Spectrosc. 3608, 185-194 (2003).

74. Rygula, A. et al. Raman spectroscopy of proteins: a review. J. Raman Spectrosc. 44, 1061-1076 (2013).

75. Czamara, K. et al. Raman spectroscopy of lipids: a review. J. Raman Spectrosc. 46, 4-20 (2015).

76. Wiercigroch, E. et al. Raman and infrared spectroscopy of carbohydrates: a review. Spectrochim. Acta A Mol. Biomol. Spectrosc. 185, 317-335 (2017)

77. McMahon, K. J., Castelli, M. E., Vescovi, E. G. \& Feldman, M. F. Biogenesis of outer membrane vesicles in Serratia marcescens is thermoregulated and can be induced by activation of the Rcs phosphorelay system. J. Bacteriol. 194, 3241-3249 (2012).

78. Pradenas, G. A., Paillavil, B. A., Reyes-Cerpa, S., Pérez-Donoso, J. M. \& Vásquez, C. C. Reduction of the monounsaturated fatty acid content of Escherichia coli results in increased resistance to oxidative damage. Microbiology 158, 1279-1283 (2012).

79. Surapaneni, M., Kabra, P., Chakraborty, S. \& Nagarajan, P. Understanding the pathway of antibacterial activity of copper oxide nanoparticles. RCS Adv. https://doi.org/10.1039/x0xx00000x (2012).

80. Malabirade, A. et al. The RNA complement of outer membrane vesicles from Salmonella enterica Serovar Typhimurium under distinct culture conditions. Front. Microbiol. 9, 1-21 (2018).

81. Kulp, A. \& Kuehn, M. J. Biological functions and biogenesis of secreted bacterial outer membrane vesicles. Annu. Rev. Microbiol. 64, 163-184 (2010).

82. Toyofuku, M., Nomura, N. \& Eberl, L. Types and origins of bacterial membrane vesicles. Nat. Rev. Microbiol. 17, 13-24 (2019).

83. Zhou, L., Srisatjaluk, R., Justus, D. E. \& Doyle, R. J. On the origin of membrane vesicles in Gram-negative bacteria. FEMS Microbiol. Lett. 163, 223-228 (1998).

84. Chutkan, H., MacDonald, I., Manning, A. \& Kuehn, M. J. Quantitative and qualitative preparations of bacterial outer membrane vesicles. Methods Mol. Biol. https://doi.org/10.1007/978-1-62703-245-2_16 (2013).

85. Menges, F. Spectragryph (Springer, New York, 2019).

86. Notingher, I., Verrier, S., Haque, S., Polak, J. M. \& Hench, L. L. Spectroscopic study of human lung epithelial cells (A549) in culture: living cells versus dead cells. Biopolym. Biospectrosc. Sect. 72, 230-240 (2003).

87. Uzunbajakava, N. et al. Nonresonant confocal Raman imaging of DNA and protein distribution in apoptotic cells. Biophys. J. 84, 3968-3981 (2003).

88. Maquelin, K. et al. Identification of medically relevant microorganisms by vibrational spectroscopy. J. Microbiol. Methods 51, 255-271 (2002).

89. Moritz, T. J. et al. Effect of cefazolin treatment on the nonresonant Raman signatures of the metabolic state of individual Escherichia coli cells. Biophys. J. 98, 742a (2010).

90. Schuster, K. C., Reese, I., Urlaub, E., Gapes, J. R. \& Lendl, B. Multidimensional information on the chemical composition of single bacterial cells by confocal Raman microspectroscopy. Anal. Chem. 72, 5529-5534 (2000).

91. Schenzel, K. \& Fischer, S. NIR FT Raman spectroscopy: a rapid analytical tool for detecting the transformation of cellulose polymorphs. Cellulose 8, 49-57 (2001). 
92. Rösch, P. et al. Chemotaxonomic identification of single bacteria by micro-Raman spectroscopy: application to clean-room-relevant biological contaminations. Appl. Environ. Microbiol. https://doi.org/10.1128/AEM.71.3.1626-1637.2005 (2005).

93. Lagant, P., Vergoten, G., Fleury, G. \& Loucheux-Lefebvre, M.-H. Raman spectroscopy and normal vibrations of peptides. Eur. J. Biochem. 148, 137-148 (1984).

94. van Manen, H.-J., Kraan, Y. M., Roos, D. \& Otto, C. Single-cell Raman and fluorescence microscopy reveal the association of lipid bodies with phagosomes in leukocytes. Proc. Natl. Acad. Sci. USA 102, 10159-10164 (2005).

\section{Acknowledgements}

This research was supported by the Utah Agricultural Experiment Station, Utah State University, and approved as journal paper number 9406. Funding from USDA National Institute of Food and Agriculture AFRI project 2016-08771, NSF CBET 1705874, and USU core microscopy facility and SEM instrumentation support from NSF CMMI 1337932 are gratefully acknowledged. We also thank Morgan Bishop and Jacob Barney for assisting with Raman spectroscopy and Anthony Cartwright for SEM images.

\section{Author contributions}

M.P. performed all microbiology experiments, O.M.V. isolations, D.L.S. characterization, and initiated the writing of this manuscript. C.H. performed Raman spectroscopy, performed L.D.A., and assigned Raman peaks. A.J.A. provided the P. chlororaphis strain and microbiology expertise. D.W.B. conceived of the project and performed AFM imaging. E.V. conceived the Raman spectroscopy methodology in this project and assigned Raman peaks. All authors critically reviewed and revised the manuscript and approved of the final version.

\section{Competing interests}

The authors declare no competing interests.

\section{Additional information}

Supplementary Information The online version contains supplementary material available at https://doi. org/10.1038/s41598-020-78357-4.

Correspondence and requests for materials should be addressed to E.V. or D.W.B.

Reprints and permissions information is available at www.nature.com/reprints.

Publisher's note Springer Nature remains neutral with regard to jurisdictional claims in published maps and institutional affiliations.

(c) (i) Open Access This article is licensed under a Creative Commons Attribution 4.0 International License, which permits use, sharing, adaptation, distribution and reproduction in any medium or format, as long as you give appropriate credit to the original author(s) and the source, provide a link to the Creative Commons licence, and indicate if changes were made. The images or other third party material in this article are included in the article's Creative Commons licence, unless indicated otherwise in a credit line to the material. If material is not included in the article's Creative Commons licence and your intended use is not permitted by statutory regulation or exceeds the permitted use, you will need to obtain permission directly from the copyright holder. To view a copy of this licence, visit http://creativecommons.org/licenses/by/4.0/.

(c) The Author(s) 2020 